\title{
GEOSITES IN THE ISLAMIC AGE, CAIRO - EGYPT
}

\author{
Kholoud M. ABDELMAKSOUD* \\ Cairo University, Faculty of African Postgraduate Studies, Natural Resources Department, \\ Giza, Cairo, 12613, Egypt, e-mail: kholoud.mali@staff.cu.edu.eg, kholoud.mohamedali@gmail.com
}

Citation: AbdelMaksoud, K.M. (2020). GEOSITES IN THE ISLAMIC AGE, CAIRO- EGYPT. GeoJournal of Tourism and Geosites, 32(4), 12591263. https://doi.org/10.30892/gtg.32410-566

\begin{abstract}
The interest of community administrations in geological heritage is now growing worldwide, the Egyptian history is the result of the confluence of many cultures that found their way to the River Nile, and influenced its native ancient civilization; one of the oldest civilizations in the world. The admix of these civilizations is what makes Egyptian geological and archeological heritage so unique. This paper focuses on an important geologic heritage in the Islamic period of Egyptian history starting in the seventh century AD. Evidence of the influence of Islamic architecture can be found throughout the city of Cairo. Cairo has a large number of Islamic archaeological sites of particular importance is the Saladin Citadel and the surrounding streets of old Cairo, these sites is considered as an important unique geosites from the point of geological heritage view. The Islamic age is well documented by historians. Whereas the hundreds of masjids (mosques) as well as the Saladin Citadel tell the story of Islamic Cairo, This article sought to demonstrate the first Islamic Geosite inventory in the old Cairo, Egypt, and to elucidate its value throughout the ages. Method: field and sample investigations used to recognize the geosites in the islamic age. The paper are showing unique segment in this age, converting the archeological Islamic sites into geosites and geological heritage value.
\end{abstract}

Key words: Archeological sites, Geology; Islamic age, Geo site, Geotourism

$* \quad * \quad * \quad * \quad * \quad *$

\section{INTRODUCTION}

Many authors worked on the geological heritage and its assessment like Gray (2013); Prosser (2013); Henriques and Brilha (2017); Ruban (2017) and Brilha et al. (2018), they discussed the Geological heritage as a unique geological phenomena to be used for the Earth sciences, education, and geo-tourism is an important geological resource of many African countries.

The historic city of Cairo covers an area of approximately $8 \mathrm{Km}^{2}$. Situated on eastern bank of the Nile, surrounded by the vast modern extensions of the residential and commercial quarters of greater Cairo. Most of the registered historical monuments dating from the foundation of Cairo in 969 to mid-19th century are located within this area. The architectural wealth of the Islamic (Medieval Cairo) is still a living reality due to the existence of important areas of the original urban fabric that shaped its physical environment.

The gradual preponderance of Islamic architecture, starting in the Middle Ages, in time led Cairo to be known as the city of a thousand minarets. Over time, the call to the Muslim prayers became audible from anywhere in the city. During the month of Ramadan and other important Muslim feasts, most of minarets were lit. Some minarets had up to 60 lamps. After sunset, the city was transformed into a magical place. Until the first half of the 20th century, what we know today as Greater Cairo was known as Misr, the Arabic name for Egypt is "Misr" (Gharib, 2017). Cairo is an unequalled treasure house of Islamic architecture. Built and over a span of a thousand years, Cairo's historic center contains the most concentrated, the most numerous, and the most varied collection of monuments in the Islamic world. But Cairo is not only a sum of its monuments; its historic center remains a dynamic urban organism. Medieval Cairo was the city where the tales of the Thousand. Over the centuries, Cairo has continued to be a literary setting. Cairo, unlike Baghdad and Damascus, was spared the devastation of the Mongol invasions (Williams, 2008).

Tangible heritage is considered by Islam as an important tool for interpreting history. An early form of what we know now as cultural tourism was put forward by the Qur'an and adopted by Muslims. Muslims are encouraged to visit the remains of previous civilizations in order to understand history better and to reflect on the meaning of life. Islam teaches Muslim visitors of such sites to abide by a strict etiquette and show the utmost respect. Muslims are instructed to observe and respect natural and cultural diversity as an essential part of their religious observance. From an Islamic point of view, local, regional, natural, and cultural diversities are seen as expressions of God's creation. The adoption of such diversities in turn led to a diversity of Islamic artistic, architectural and urban heritage in different regions of the world.

Islamic archeology emerged as an independent field of inquiry that studies a period that spans hundreds of years. Initially, it developed relatively slowly compared with other branches of archeology, but has since gained con siderable momentum (Vernot, 1997).

The exquisite nature of architecture the Islamic period can be seen throughout Cairo. Marveling at the beauty of such archite cture, a question remains as to how much science was involved in the erection of the mosques and other buildings. Clues throughout Islamic Cairo suggest that geology had evolved into a well-established science. For example, ornamental stones used in building mosques were evidentiality acquired from old quarries first used in ancient Egypt (Figure 1). Evidence also indicates that, in choosing the site of the Aladdin Citadel, avoidance of geo-hazards were taken into consideration.

AbdelMaksoud and Emam (2019) studied the importace of geology in the Ancient Egypt and they linked almost all branches of geology as an ancient science studied in the Pharonic age in ancient Egypt, the mentioned the important geosites and their assessment to geological heritage, this previous study open a new vision to see the geosites found in other previous ages like the Islamic age.

Many authors described how to evaluate a geosite Gray (2013); Prosser (2013); Henriques and Brilha (2017); Ruban (2017) and Brilha et al. (2018); AbdelMaksoud and El- Metwaly (2020); AbdelMaksoud (2020) which can be summarized in the geologic importance in the site, and archeological importance if found (not all geosites linked to archeological places but if found increased the rank and the importance of the site), finally the unique of this geologic heritage in the site. The study are presented in this paper are proposing 3 geosites in the old Cairo depending on its geological value and archeological importance. The main objectives are characteristics of this unique geosites, this study employs the Islamic geosites as a representative example of Archeological geosite -related to geological heritage assessment in Cairo- Egypt.

\footnotetext{
${ }^{*}$ Corresponding author
} 


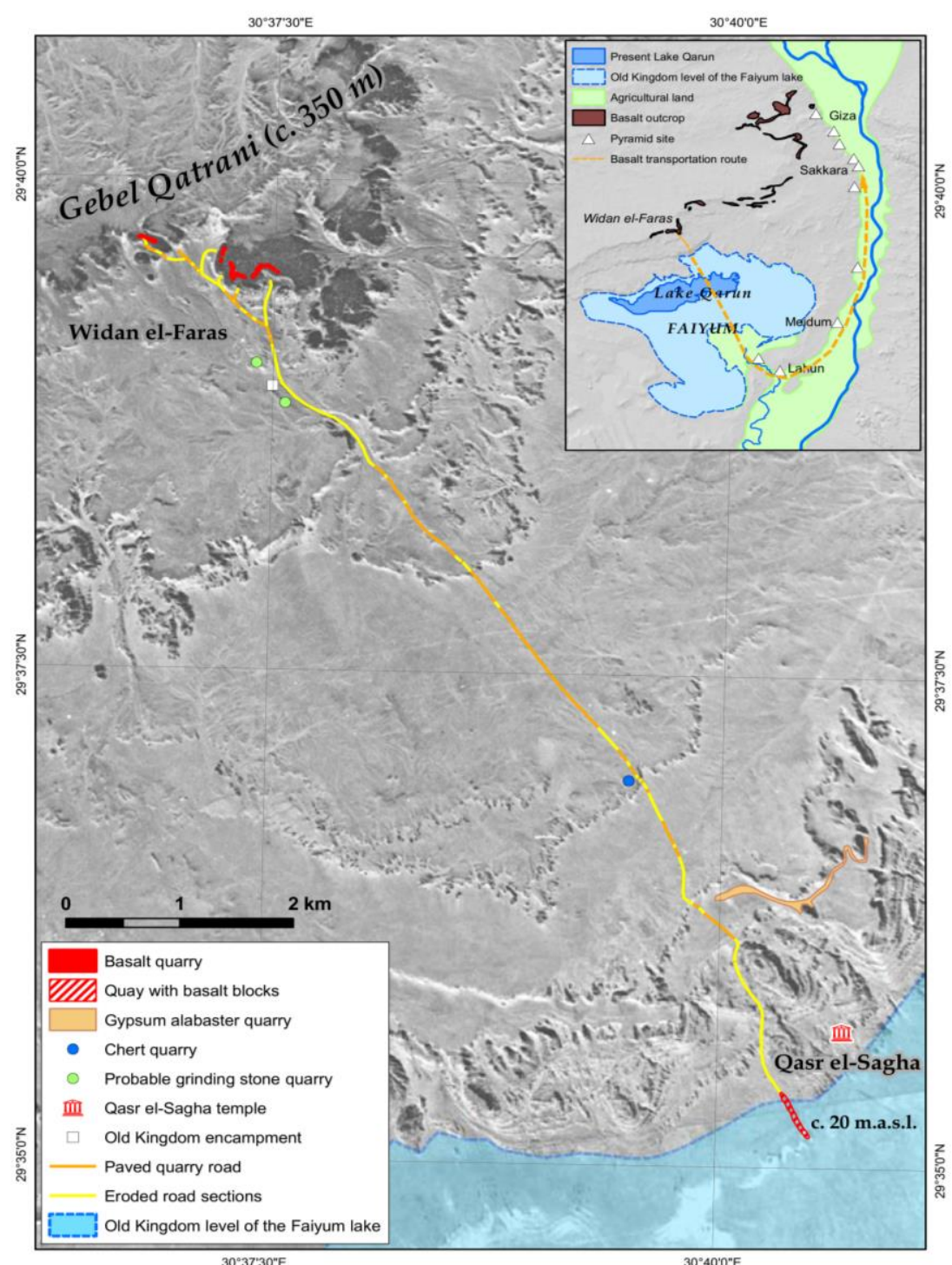

Figure 1. Ancient quarries used for ornamental stones since Phoars, passes through Roman time and Islamic age, after Harrell and Storemyr (2009)

\section{MATERIAL AND METHODS}

\section{Ornamental Stones Geosite}

Some authors worked on the value of ornamental stones in the geological heritage as geosites; Todaro (2019); Wever et al., (2017); Brilha (2016) mentioned that the value of monumentstand building is getting high by the presence of Ornamental stones with educational and touristic values, Sites with high tourism value can also be known as geomonuments; this term is already used to promote geosites to the general public in some countries, this describtion is perfectly applied on Ornamental stones of ancient Egypt were cut out of a diverse group of rocks. These stones were well sought after for their gorgeous colors and patterns and ability to take a good polish. They had a variety of decorative applications in both art and architecture. At least 48 varieties of ornamental stone were used by the Egyptians. These come from 45 well-known ancient quarries; two in northern Sudan and the rest in Egypt (Harrell, 2013).

Harrell, (2013) stated that dozens of types of ornamental stones were also imported into Egypt from around the Mediterranean region during the Roman Period. They were used for statuary and especially architectural elements in villas, temples, and public buildings. Much of this material was later reused in Egypt's medieval mosques and other Islamic monuments, where stones were employed as floor tiles, wall veneer, columns, and other decorative applications (Rogers, 1976; Harrell, 2004b; Harrell et al., 2002b). Some of this material has also been reused in Coptic Christian churches. In Egypt, Muslim builders of the Middle Ages evidently understood and applied some of the basics of geology to their work. They used ornamental stones that they had quarried and polished to decorate citadels, palaces and mosques (Figure 2). Like the ancient Egyptians before them, they also used gemstones as accessories in a variety of ways (AbdelMaksoud and Emam, 2019).

\section{The Saladin Citadel Geosite}

Another example of geologic architecture is the citadel founded in Old Cairo during the reign of Saladin. Understanding the choice of the Mokattam Plateau Figure 3 as a site of the citadel may, at first, seem like an oddity. This plateau is comprised of sedimentary rock that contains swelling clays which may crack and slide. People who live in the area today use moisture barriers to prevent the clay from swelling and sliding. On initial examination, the plateau does not seem ideal for the erection of a fortified citadel. And yet, the 837-year old citadel still stands to date and shows no evidence of fractures. The original builders of the citadel had dug a water well inside the citadel to provide water for soldiers. The nature of sedimentary rocks would suggest that such a well would eventually crumble over, but the well has stood the test of time. Did those responsible for erecting this citadel consider the nature of this sedimentary rock and the potential problems it would create before they had started to build the citadel? Why, despite all the aforementioned potential problems, was the plateau chosen to build the citadel? 


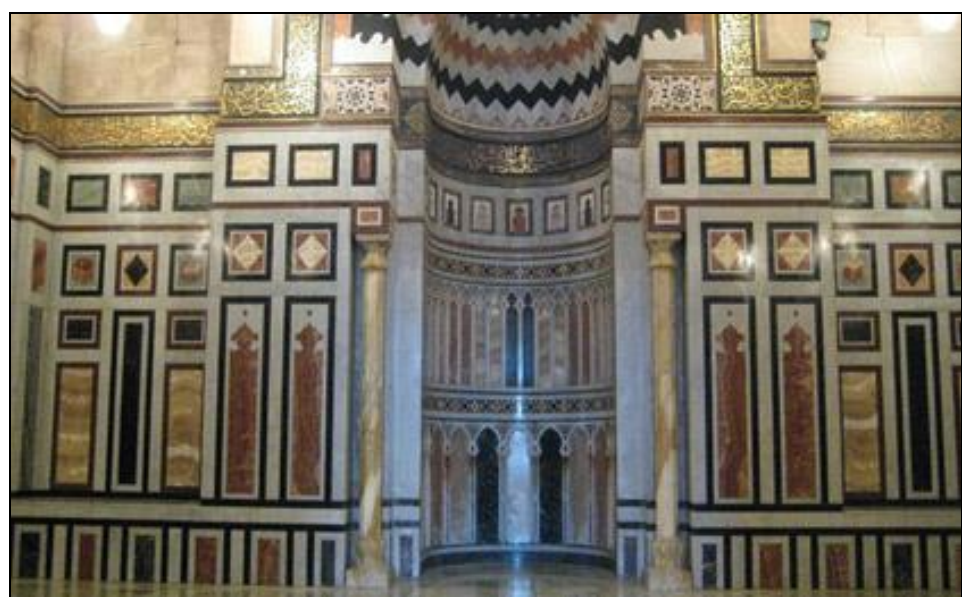

Figure 2. Shows a master piece in one of the most popular mosques in Old Cairo, this figure contains more than 4 types of stones; The Egyptian alabaster, one most famous sones in Egypt (white creamy), Serpentinte (green stone),

Red Marble (fleshy red), Black marble (black). Using ornamental stones in the Islamic Period for decoration of Mosques

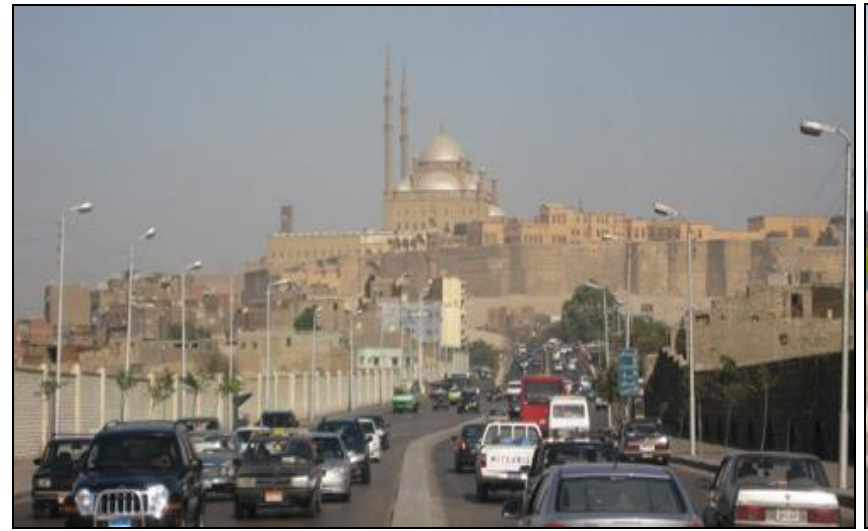

Figure 3. Saladin Citadel

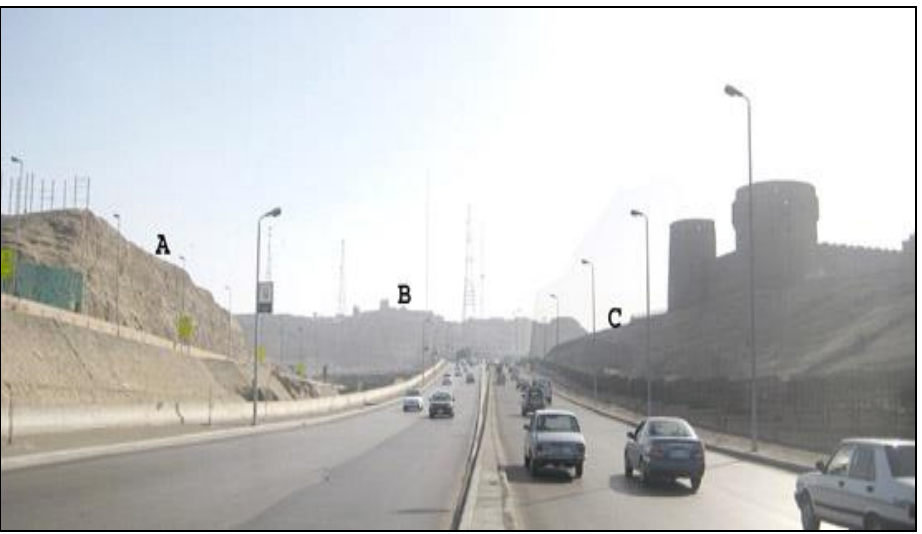

Figure 4. S Panoramic view showing differences in elevation. "C" is the citadel plateau while A \& B are the opposite plateaus

Boukhary et al. (2010) addressed this question. Their conclusions may be summarized as follows:

1. The plateau chosen as a site for the citadel was not the highest plateau in the area. Some of the surrounding plateaus were higher (Figure 4). Inarguably, other characteristics of the Mokattam Plateau must have been taken into consideration. And yet, historians have stated that Saladin had chosen this site due to its elevation, which would have provided him a clear view of Old Cairo to "watch over" it (Rabbat, 1995; El- Harthy, 1999).

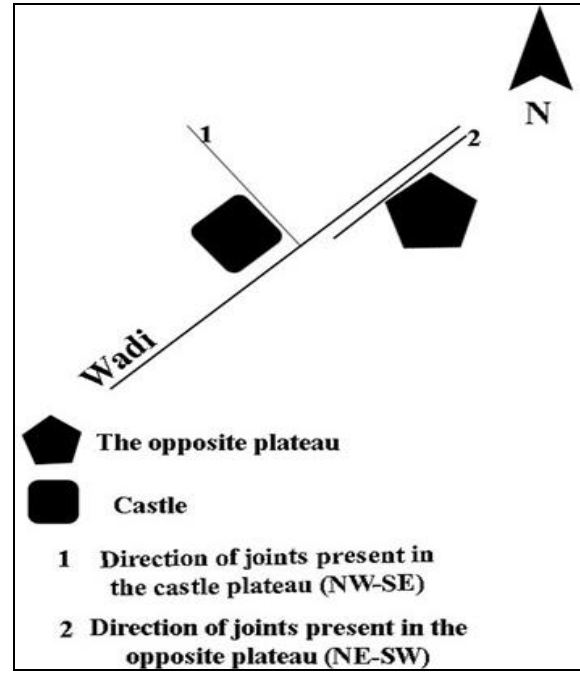

Figure 5. Schematic diagram showing joint direction in comparison with valley direction

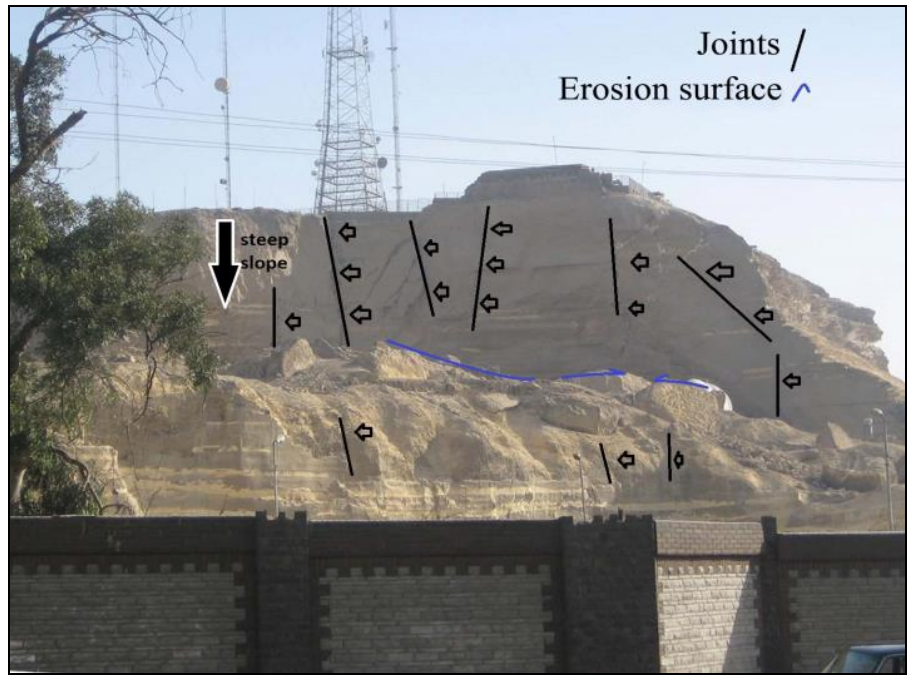

Figure 6. The plateau opposite to that of the citadel, showing joints in paralle to the valley. The photo was taken from the valley. Note the steep slope and the erosions

2. Upon careful examination of joint direction of both the Mokattam Plateau and other surrounding plateaus two sets of joints, vertical and horizontal are discovered. The vertical joints along the plateau opposite to the citadel plateau run NE-SW, while the vertical joints present in the citadel plateau run NW-SE (Figure 5 and Figure 6). The vertical joints present in the citadel plateau are perpendicular to the direction of the valley below, a feature which probably prevented blocks from sliding over the years (Figure 6). 
3. As shown in Figure 8 and 9, the citadel plateau has a gentle slope, while the opposite plateau has a steep slope (Youssif, 2000; El-Shoby et al., 2004). It is well established that gentle slopes are better for construction than steep slopes which are more susceptible to erosion.

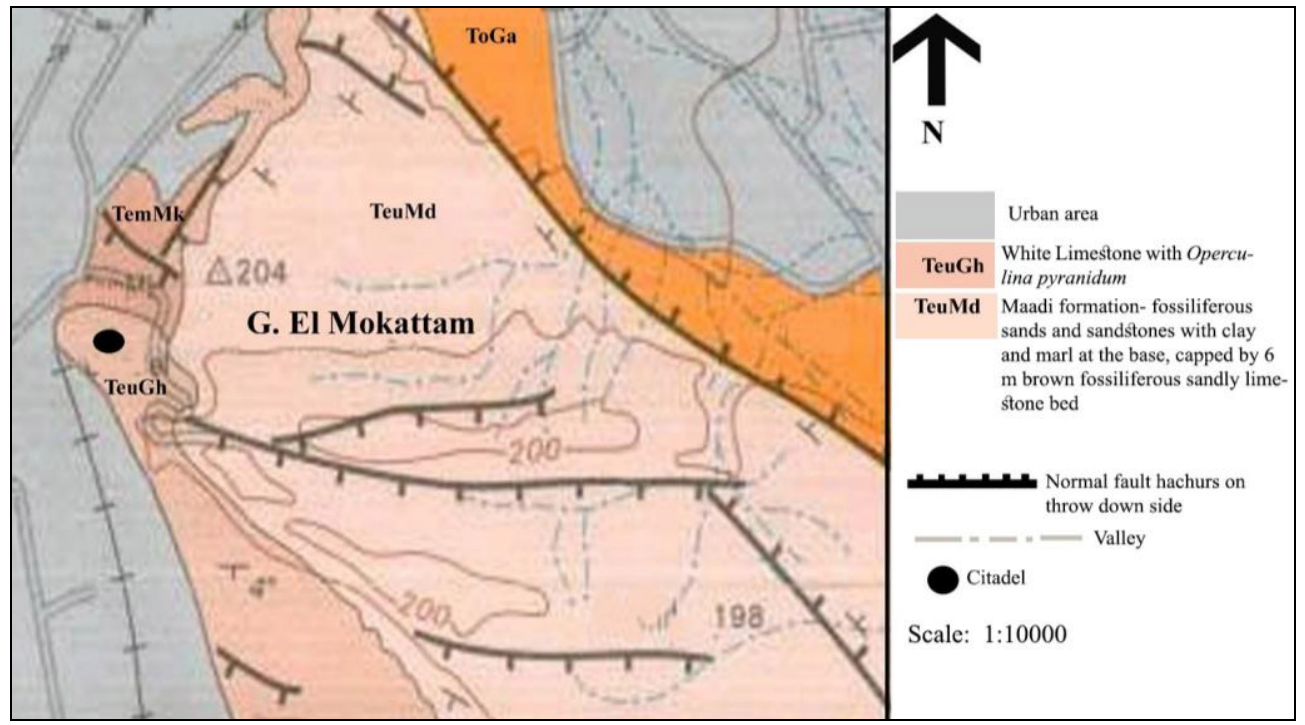

Figure 7. Geologic map for the Citadel area (Source: after the Egyptian Geologic Survey, 1984)

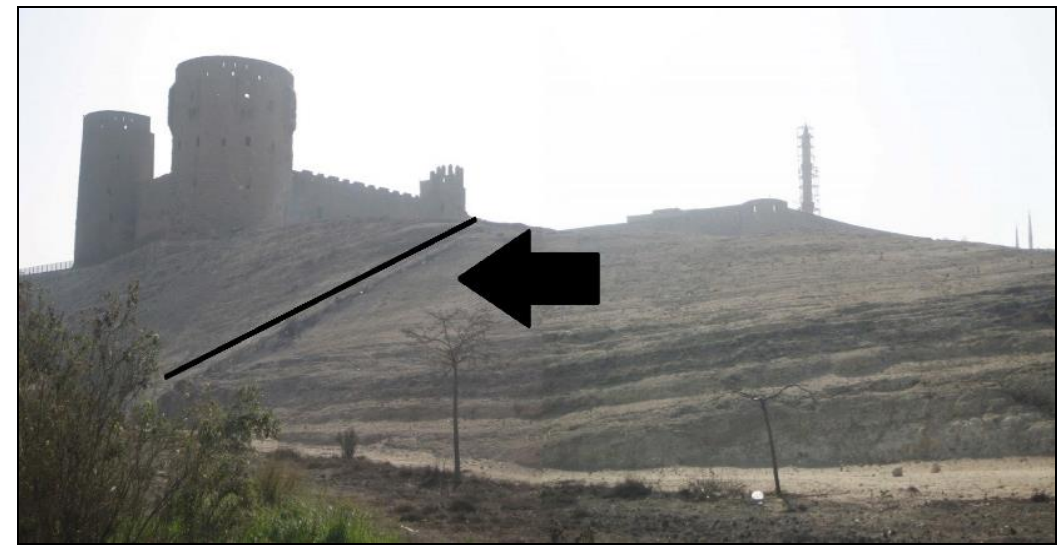

Figure 8. The citadel plateau. Note the gentle slope by the black arrow and the line show the slope

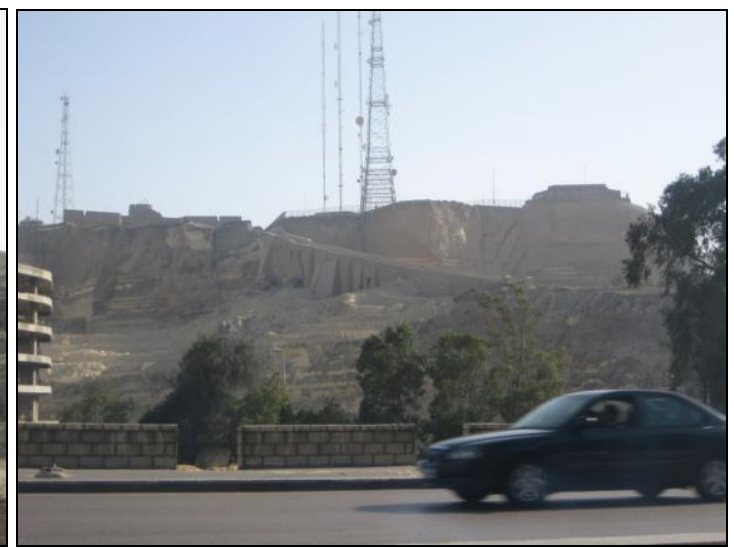

Figure 9. The steep slope of the plateau opposite to that of the citadel

4. The exposed rocks of the Mokattam Plateau have a total thickness of 166 meters (Mustafa et al., 1991). These rocks date back to the middle and late Eocene ages based on their lithostratigraphic sequences which were studied by Shukri (1954) and Strougo (1986). The Maadi formation is made up of a series of easily identified, well-developed brownish beds of fissured limestone, marl and shale, while the section housing the citadel is made up of white to gray massive limestone. According to Aboushook and Sherif (2000), the section that includes the citadel is is more resistant than the Maadi formation and, as a result, an erosion surface separates the two, which makes the section chosen for the citadel more suitable than other surrounding hill sites. Boukhary et al.'s (2010) conclusions clearly suggest that the early builders of the citadel had carefully considered their choice of location of the Saladin Citadel in order to minimize any possible geological hazards.

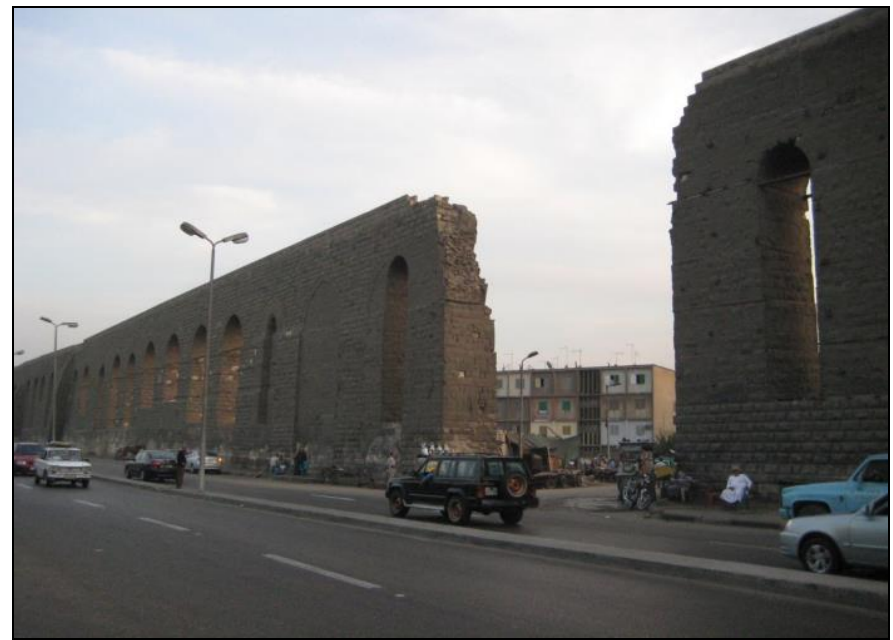

Figure 10. The Magra El Eyoon Aqueduct

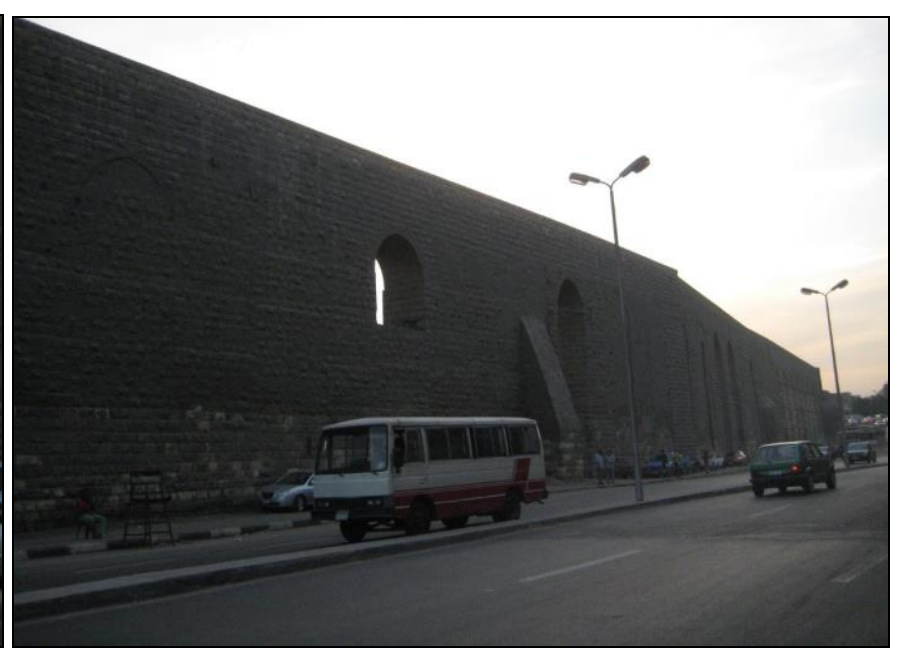

Figure 11. Another view of the aqueduct, showing its height and length 


\section{The Magra El-Eyoon Aqueduct Geosite}

This structure was built to transferring water from the River Nile up to the plateau. Similar structures to Magra El Eyoon or the 'waterway' in English were built in ancient times (Figures 10 and 11). Magra El Eyoon is a large wall, $7 \mathrm{~km}$ in length and about 30 meters at its greatest height, and is considered to be unconventional architecture. There is no researchers worked on the geology of the rocks in the researchers worked on the improvement of this place as a touristic place (Khalil, 2014) mention the in her work and makes a licker account with very interesting photos for the whole place (https://www.flickr.com/photos/13747511@N07/sets/72157627827313575).

The structure of this proposed geosite is Dolomitic they used this kind of rocks to build this structure, likely because of its impermeability to water, also they cemented the with clay, this proposed geosite was built in Salah al-Din era to transport water from the Nile to the castle and farming area near the castle. When the castle widened, Sultan al-Nasir Muhammad IbnQalawun developed the adqueduct to transport water more to the castle (http://arabicivilization2.blogspot.com/2008/12/blogpost_25.html).

\section{RESULTS AND DISCUSSION}

Egypt richness of the geological heritage makes it very suitable for investigation and exploitation, the rise of which has started recently. However, the knowledge of unique geological phenomena of this country remains restricted, and some promising locations as well as the entire types of geological heritage need assessment.

Despite the large amount of scientific publications on these region's geology and the occurrence of several sites of international importance, the regional government has not yet included geological heritage in its policies related to the conservation and management of nature.

Predominantly, the geological heritage resource can be engaged effectively for generating additional income to regional and national budgets, supporting sustainable development of the country. One of the aims of this paper is to insist on the relevance of inventorying and preserving archeological sites that will not be mentioned as geological importance. The present inventory encompasses few locations in old to be listed as geosites. It is imperative not only to highlight their existence, but also to point them out as possible geotouristic resources with its archeological and Islamic value. A deep knowledge of the geosites will allow its integration in administrative and legal processes.

\section{CONCLUSION}

The present proposal for the inventory and assessment of geological heritage and geosites geodiversity sites can be applied in different settings, in different size areas, and under diverse legal contexts (geotourism). Despite of the assessment method used for geosites, it should be highlighted that a final reflection about the obtained results is essential.

There must be scientific coordinator of the inventory to confirm the quality of the results and search for eventual ranking positions for the three proposed geosites. Though, the three geosites proposed in this paper can surely. In fact, this assessment has one perspective; it tries to evaluate the scientific value of sites and the potential educational and touristic use of geosites. This difference is due to the fact that a geosite should be conserved for its geological value individualistically of its effective touristic usage. Finally, the assessment of the three geosites should be Protected and managed for paramount rank both for science and other societal uses.

\section{Acknowledgement}

The author wished to thank Dr. Mohamed GabAlha and Mr. Mahmoud Emam for their helpful comments on earlier drafts of this paper; the authors deeply acknowledge to anonymous reviewer for their thoughtful suggestions and comments.

\section{REFERENCES}

AbdelMaksoud, K.M. (2020). Al Fawakhir Gold mine as a Geosite, Eastern Desert, Egypt. International Journal of Earth Sciences, 109(1), 197-199. https://doi.org/10.1007/s00531-019-0181-w

AbdelMaksoud, K.M., \& El Metwaly, W. (2020). Maadi Petrified Forest in Cairo, Egypt, as a Geologic HeritageUnder Urbanization Pressure. Geoheritage, 12, 1-11. https://doi.org/10.1007/s12371-020-00465-4

AbdelMaksoud, K.M., \& Emam, M.A. (2019). Hidden Geology in Ancient Egypt. Geoheritage, 11(3), 897-907. https://doi.org/10.1007/ s12371-018-0338-4

Boukary, M., Hussien, I.A., \& Kaml, Y.H. (2010). Nummulities crassichodatus n.sp (N. Laevigatus group, foraminifera from the middle Eocene of the Citadle section, Gebel Mokattam, Egypt. Revue de Palebiologi, Geneve 29(1), 185-196.

Brilha, J. (2016). Inventory and quantitative assessment of geosites and geodiversity sites: a review. Geoheritage, 8(2), 119-134

Brilha, J., Gray, M., Pereira, D.I., \& Pereira, P. (2018). Geodiversity: an integrative review as a contribution to the sustainable development of the whole of nature. Environ Sci Policy 86, 19-28, https://doi.org/10.1016/j.envsci.2018.05.001

Cooper, J. (2014). The Medieval Nile: route, navigation, and landscape in Islamic Egypt. The American University in Cairo Press.

De Wever, P., Baudin, F., Pereira, D., Cornée, A., Egoroff, G., \& Page, K. (2017). The importance of geosites and heritage stones in cities. Geoheritage, 9(4), 561-575.

El-Harthy, M.F. (1999). Urban of Cairo and its design in Salah El-Din era, Al-Zahraa Library, Cairo, Egypt. (Arabic Reference), pp. 447.

El-Sohby, M., Aboushook, M., \& Mazen, O. (2004). Slope degradation and analusis of Mokattam plateau, Egypt. 2nd International conference on geotechnical site characterization (ISC-2), Porto, Portugal, pp. 1081-1887.

Gharib, R.Y. (2017). Preservation of built heritage: an Islamic perspective (1). Journal of Cultural Heritage Management and Sustainable Development, https://doi.org/10.1108/JCHMSD-04-2016-0026

Gray, M. (2013). Geodiversity. Valuing and conserving abiotic nature. Wiley - Blackwell, Chichester, pp. 495.

Harrell, J.A. (2004b). Ornamental stones used in the zawiya/sabil of Farag Ibn Barquq in the Bab Zuwayla area of Cairo. Bulletin of the American Research Center in Egypt 185, pp. 18-23.

Harrell, J.A. (2013). Ornamental stones. UCLA Encyclopedia of Egyptology, 1(1).

Harrell, J. A., \& Storemyr, P. (2009). Ancient Egyptian quarries-an illustrated overview. Geological Survey of Norway Special Publication, 12, 7-50.

Harrell, J.A., Lazzarini, L., \& Bruno, M. (2002b). Reuse of Roman ornamental stones in medieval Cairo. Egypt. In ASMOSIA VI: Interdisciplinary studies on ancient stone: Proceedings of the Sixth International Conference of the Association for the Study of Marble and Other Stones in Antiquity, Venic, ed. Lorenzo Lazzarini, Padua: Bottega d'Erasmo - Aldo Ausilio Editore, pp. 89 - 96.

Henriques, M.H, \& Brilha, J. (2017). UNESCO Global Geoparks: a strategy towards global understanding and sustainability. Episodes 40, 349-355.

Khalil, O. (2014). The people of the city. Thesis, The Amircan University in Cairo.Prosser CD, (2013), Our rich and varied geoconservation portfolio: the foundation for the future. Proc Geol Assoc 124, 568-580.

Rabbat, N.O. (1995). The Citadel of Cairo: A New Interpretation of Royal Mameluk Architecture. E.J. Brill, ISBN-13:978-9004101241

Brill, R., \& Michael J. (1976). The stones of Barquq: Building materials and architectural decoration in late fourteenth-century Cairo. Apollo 170, (Vol. 14), pp. 307-13.

Ruban, D.A. (2017). Geodiversity as a precious national resource: a note on the role of geoparks. Res Policy, 53, $103-108$.

Shukri, M.M. (1954). The geology of the desert east Cairo. Bull.L, Institut Desert d, Egypt, Tome, 3(2), 89-105.

Stakhov, A. (2006). The golden section, secrets of the Egyptian civilization and harmony mathematics, International Club of the Golden Section. 6 McCreary Trail, Bolton, Ont., Canada L7E 2C8.

Todaro, S. (2019). The Potential Geosite of the "Libeccio Antico". Quarries: a Sedimentological and Stratigraphic Characterisation of Ornamental Stone from Mt Cocuccio, Custonaci Marble District, Sicily, Geoheritage, 11(3), 809- 820.

Vernoit, S. (1997). The rise of Islamic archaeology. Muqarnas, 14, 1-10.

Vernon, L. (1997). British Colonial Rule in Sarawak 1946-1963. Oxford University Press South-East Asian Historical Monographs, xxv, 424, Oxford University Press.

William, C. (2006). Reconstructing Islamic Cairo, forces at work. In Singerman, D. \& Paul, A. Cairo cosmopolitan, politics, culture, and urban space in the new globalized Middle East, pp. 269-294. Cairo, AUC Press.

Youssif, M.S. (2000). Slope stability of the middle Eocene rocks of Gebel El-Mokattam. ICEHM, Cairo University, Egypt, pp.14-32. 